\title{
Téoros
}

Revue de recherche en tourisme

\section{Understanding Tourist Beaches as Eco-social Landscapes Seeking Sustainability through Integration of Human and Non-human Wealth Production}

\section{Jeff Baldwin}

Volume 26, numéro 1, printemps 2007

Tourisme dans la Caraïbe : logiques régionales et perspectives de développement

URI : https://id.erudit.org/iderudit/1070994ar

DOI : https://doi.org/10.7202/1070994ar

Aller au sommaire du numéro

Éditeur(s)

Université du Québec à Montréal

ISSN

0712-8657 (imprimé)

1923-2705 (numérique)

Découvrir la revue

Citer cet article

Baldwin, J. (2007). Understanding Tourist Beaches as Eco-social Landscapes:

Seeking Sustainability through Integration of Human and Non-human Wealth

Production. Téoros, 26(1), 40-45. https://doi.org/10.7202/1070994ar 


\section{Understanding Tourist Beaches as Eco-social Landscapes}

\section{Seeking Sustainability through Integration of Human and Non-human Wealth Production}

\section{Jeff Baldwin}

\section{Introduction}

While tourism development can have significant affects on environments, much of the critical scholarship on tourism and its affects on local places have focused upon social impacts. As noted by researchers working in the tropical Pacific (Minerbi, 1992; Wong, 1993) and in the Caribbean (Burac, 1996; Wilson, 1996), the environmental effects of tourism can be especially significant on small islands. Though Edington and Edington (1986) recognized the need for better understandings of ecological processes that closely interact with tourism, Hall and Page have recently lamented the continuing poverty of such understandings (1996: 6; 1999: 86).

Antigua, a small island in the West Indies, provides a good illustration of how tourism might affect environments and environments affect tourism, and how we might understand and manage those interactions more effectively for all concerned. The tourism industry employs over half of the Antiguan labour force, generates a per capita GDP (gross domestic product) of US\$7500, and is directly responsible for $60 \%$ of the island's GDP (ABDT, 1996; ABMF, 1996; EC, 1996; The Courier, 1997 : 36; Gortier, 1997 : 32). Over 95\% of all hotel rooms are in beach resorts. Antigua is known for and promoted as a place for quiet and/or romantic beach vacations. Peter Ramrattan, the head of Antigua's Hotel and Tourism Association, characterized the island's tourist clientele as the "newly wed and the nearly dead" (1997). Though now adding "The heart of the Caribbean" to the Antiguan brand, the slogan "365 powdery white sand beaches... one for every day of the year" has been used for decades (AHTA 1996, 31).

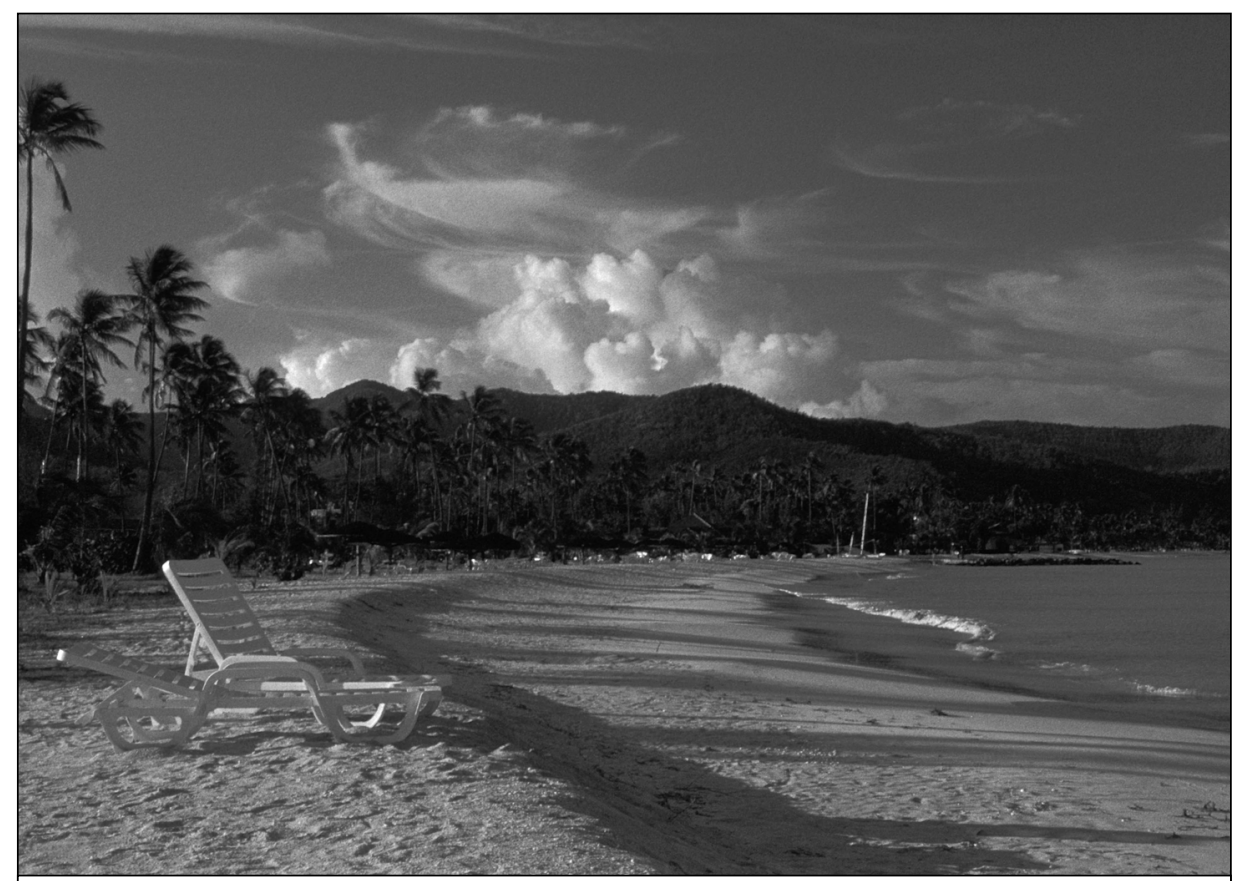

The constructed beach at Jolly Harbor, Antigua. Both sand and palm trees are imported to construct a simulacra of a tropical beach.

Photo: Jeff Baldwin

The social construction of beaches as tourism places has been well explored generally in Corbin (1994), Lencek and Bosker (1998), and Shields (1990). The relationship between Antigua's coastal environment and the governance of tourism development has been complex and highly problematic. I have described the conflictual social processes specific to Antigua's beaches elsewhere and refer the reader to discussions for further background (Baldwin, 2000, 2005; see also Coram, 1993, Patullo, 1996, and Bunce, 1997). While those social processes are central to the dialectic amongst Antiguan coasts and their users, the physical condition of the coast has recently become equally worthy of consideration. In 1996, it became clear that Antigua's beaches were eroding (AHTA 1997 : 3; CCA 1991; COSALC 1996; UPR 1994) and that the environmental basis of Antigua's national tourism economy was disappearing into the Caribbean.

In Antigua, the Government is also charged with, and is the only agent capable of caring for common lands and resources such as its beaches. Also typical of landscapes caught up in the extensification and intensification of economic activity (i.e. development), the Antiguan Government has not responded effectively to environmental degradation; consequently, beach erosion now threatens the well-being of Antigua and its people. 


\section{Alternative Paradigms for Managing Tourism Environments}

There are several alternative paradigms tourism planners may turn to as they seek to mediate the environmental impacts of tourism development. Sustainable development, environmental indicators, and "whole economies" have all been recommended. While each of those planning frameworks seeks to integrate economy with ecology, they all have inherent problems in their application to tourism-environment relations generally, and in Antigua in particular.

Some have suggested that the solution to environmental impacts lies in better monitoring through environmental indicators. In a critique of using "indicators" to manage reef health in tourism areas, Butler (1993: 39) notes that visitor declines are among the most common indicators of non-sustainability and that, in "many cases, such indicators come too late for satisfactory remedial action, even if that had been possible". As Hall and Page (1999: 52) assert, index driven technical fixes often maintain the appearance of normalcy, while environmental degradation continues. To address problems such as beach erosion in a sustainable way, one must first understand how beaches are produced by non-human and non-market processes, and then identify how those processes have changed and what role tourism development has played (Hughes, 2002).

Where sustainable development fails by dichotomizing humans from nature, relying upon rational management, technical fixes, and insufficient environmental indicators, the authors of "whole economy" frameworks attempt to bridge the divide between the "conditions of production" (nature and not-for-market human production) and production for exchange. In their application of the whole economy paradigm to tourism development in Pangandaran, Indonesia, Harris and Nelson (1993) attempt to encompass abiotic processes, but treat non-human activity as inert "spatial resources" whose value arises purely useful to humans.

Those alternative techno and econocentric paradigms share a fundamental and problematic model of environments as mechanistic and passive. However, environments are not immune to human use. They respond to and change with human activity as they do to all disturbances. In Antigua, developers have treated beaches as passive or dead objects that are motivated by physical forces. Beach erosion, therefore, has been categorized as an engineering problem whose solution lies in moving sand from artificial jetties, reef bottoms, and Antigua's sister island, Barbuda, and depositing it in front of resorts (Zachariah, 1997a and 1997b; Baldwin, 2000). However, in the long term, such technocentric management has only exacerbated the problem of beach erosion.

In order to understand beach erosion, it is important to understand beaches. Briefly, throughout the insular tropics, most beach sand is biogenic, i.e. it is produced by living organisms. Such beaches are primarily composed of the accumulated bodies of calcium carbonate fixing corals and microalgae (hereafter referred to as coralgal communities), and free floating foraminifera living in the reef environment (Inman, 1994: 80). Wave action breaks those calciferous bodies and moves them across the sea floor, often depositing them on shore where they form beach berms. In addition to supplying sand to beaches, those living communities create sea floor roughness that works to moderate erosive wave energies (Symonds et al., 1995; Gourlay, 1994; Young, 1989). Coralgal communities thus produce and maintain beaches.

Dredging sand from offshore reefs for beach nourishment is problematic to that process on several counts. Dredging physically destroys portions of the living sand sources. In addition, it mobilizes fine sediments that can require years to sequester. Those fine sediments hurt coralgal communities in several ways. They cause turbidity that decreases photosynthesis and growth both among the tiny palm tree shaped Halimeda alga and the zooanthellae alga that live symbiotically in coral polyps. When the fine sediments do settle, they can mantle microalgae and corals, neither of which have the ability to uncover themselves. Finally, when fine sands are deposited upon beaches, they are easily remobilized by wave action and moved back over the coralgal community. Nourishment can increase turbidity and degrade coralgal communities for years.

\section{New Conceptual Tools}

Planning for sustainable development could be made more effective by changing two conceptual fields, both of which arise from assumptions that humans and non-humans are essentially different. As Costanza, Wainger, and Bockstael (1995) observe, research into systems tends to dichotomize our worlds into economic or ecological models. Ecological models tend to include humans only as exogenous disturbances and economic models tend to reduce ecology to a set of constraints. In that rubric, "the studies are completed using different terms and units of measurement, and the studies neglect to account for the interaction between the processes and populations" (idem: 45). A category is needed that is capable of encompassing all production, all value. Secondly, ecological systems are not well described as passive or as mechanically manageable.

\section{Wealth}

To reconceptualize wealth in a way that seeks similarities between humans and other life, it is helpful to categorize wealth by what it does, rather than what it is. Such a categorization leads to two propositions: first, broadly defined, wealth is anything that has value to some valuing entity; and second, wealth is inessential matter-its value is relative and its form is changed by living beings into other forms. Though one cannot ask non-humans what they value (Laycock, 1999), valuing can be observed empirically by watching for choice (Goodpaster, 1978; Plumwood, 2002). Coral polyps, for example, differentially anchor to surfaces that are sunnier than those that are less so (Baldwin, 2006). In that practice, they demonstrate choice, and therefore valuing. Corals value sunlight because the zooanthellae algae that live behind a thin transparent membrane covering the hard calciferous surface of the polyps' shell produce carbohydrates through photosynthesis. In their life-activity, the zooanthellae transform sunlight, water, and nutrients (some of which are the by-product of the corals' life-activity) into food, which corals depend upon. As life is distinct in its self-organization, life is also marked by its intentional transformation of energy into matter and information, information into energy and matter, and matter into energy and information (after Bourdieu, 1986). All fit into the category of wealth, which is understood functionally as matters useful to life in its drive to extend itself in time and space. 
As "embodied selves," we humans are complex wealth-transforming and wealth-managing mechanisms. Through and in our physical being, we organize stores and flows of power, knowledge, and money. We transform one into the other as needed, according to our abilities. In that life activity we are very much like a plant transforming sunlight, nutrients into material wealth, in accordance with genetic and environmental information. Humans do what life does. All life organizes flows and accumulates stores of wealth. Through their activity, living beings transforms each of those inessential categories of wealth into the other (Lefebvre, 1991: 176; Foucault, 1970 : 274-278).

Despite the constant turnover of energy and materials, there is a net increase in the mass of the complexes (i.e. living beings) at higher levels of structure $(H o, 1993)$. Life is marked by its ability and insistence upon organizing flows of matter and energy into coherent forms in accord with information stored within individuals and taken from their environments. Coherence is a helpful concept in grasping processes that are at once transient and permanent.

We create security in stabilizing those flows, our access to them, and their access to us. Life is unique in this, it is distinguished by it. Unlike an inanimate dynamic form such as a standing wave, living beings are not constituted solely by external forces; they act to bring those flows to and through themselves. Life reaches out into the world. Serres (1982) suggests that we think of organisms as seeking homeorrhesis (constant flow), rather than homeostasis (constant state).

\section{Applying New Tools to Planning}

People concerned with the sustainable use and development of resources such as tropical island beaches are obliged to attend to the flows that create and maintain those highly valued sandy strands to reefs and coralgal communities. More importantly, in order to attain sustainable use of beaches and coasts, one should ask what inputs do coralgal communities value and which it abhor, which flows are wealthy and which are damaging.

\section{Carte 1}

"Map North" - Northern Caribbean Coast of Antigua:

tourism - and resort - related landscape alterations before development and currently.

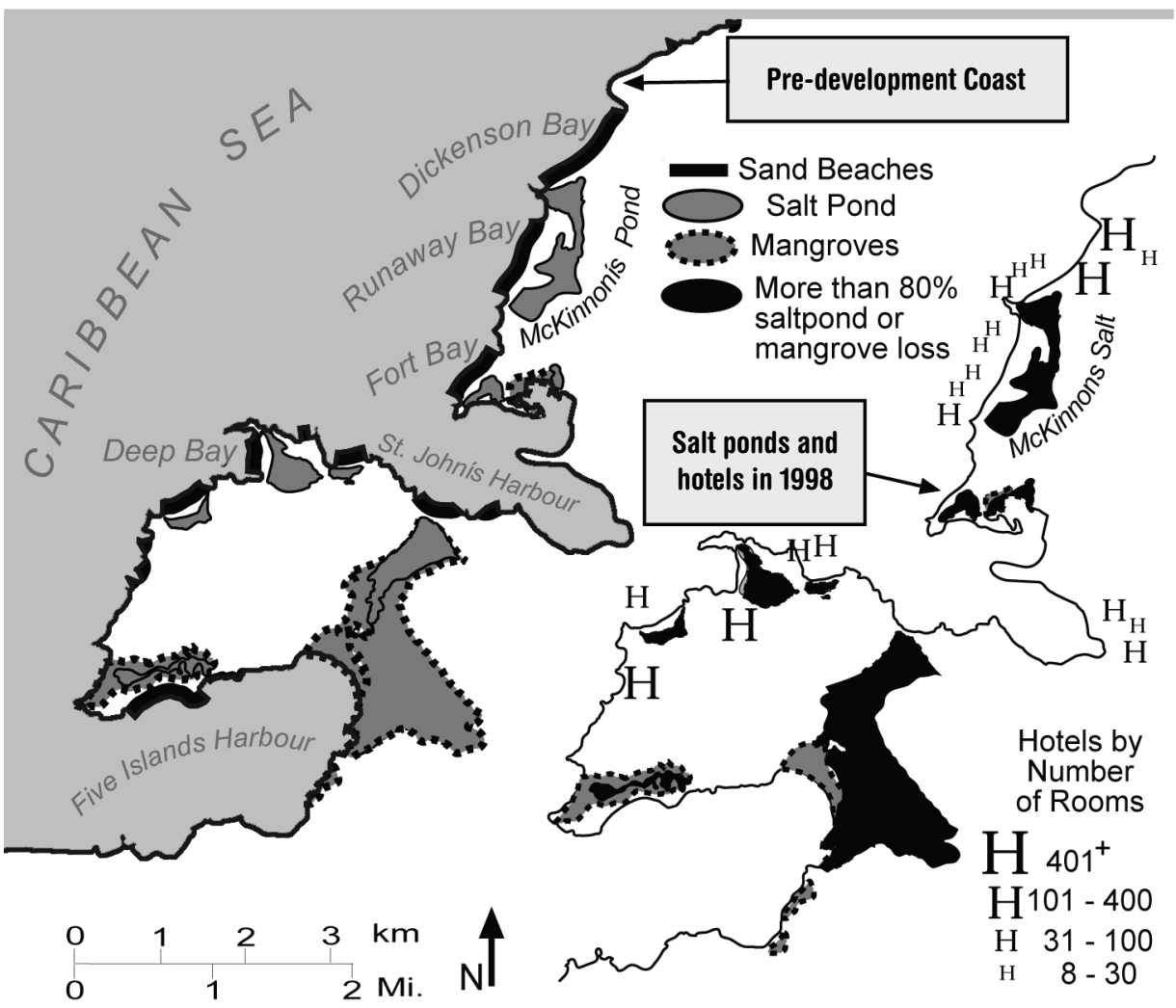

* Beaches are not shown on the contemporary coastline as their extent remains largely unchanged.

Source: Author field survey 1997; ABLSO 1991; Multer et al., 1986; DOS 1977; DOS 1962.

While resilient to indigenous disturbances such as hurricanes, coralgal communities can be seriously damaged by flows of terrestrial sediments and nutrients. Both flows interfere with coralgal photosynthesis. Sediment flows can mantle small and immobile corals and microalgae. Excessive nutrients allow large leafy macro-algae to grow rapidly and shade the coralgal community from the sun (Maragos, 1993). Fieldwork and historic environmental information indicate that tourism-related "development" on Antigua's coasts has increased both sediment and nutrient flows onto reefs. That has occurred primarily as a result of disrupting or destroying the basin mangroves that formerly filtered terrestrial runoff (Mumby et al., 2003; Tam and Wong, 1995.

On the northern portion of Antigua's Caribbean Coast, several large salt ponds have been degraded: McKinnon's through closing its tidal channel and excessive sewage dumping, Deep Bay through denudation, and the largest basin mangrove on Antigua was filled with spoil from the government's deepening of St. John's Harbour, a project undertaken to accommodate cruise ships. The illustration shows the coastal environment and close association of salt ponds and beaches prior to tourism development. The contemporary condition of intertidal mangroves and the location of hotels are superimposed to the left of that historic coastline (author field survey 1997; ABLSO 1991; Multer et al., 1986; DOS 1977; DOS 1962).

The illustration shows the coastal environment and close association of salt ponds and beaches prior to tourism development. The contemporary condition of intertidal mangroves and the location of hotels are superimposed to the left of that historic coastline (author field survey 1997; ABLSO 1991; Multer et al., 1986; DOS 1977; DOS 1962). 


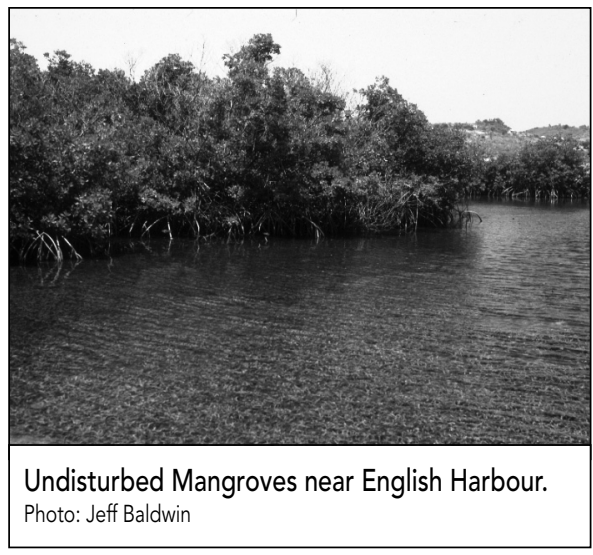

On the southern portion of Antigua's coast, there were many smaller ponds in addition to three large intertidal basins. The two largest ponds near Ligum Vitae Bay were completely altered in a dredge and fill operation associated with the construction of Jolly Harbour Resort. The large Darkwood pond near Ffryes Point was drained through channelization, and mined for sand. Many of the smaller ponds have also been mined and, like McKinnon's Pond to the north, their tidal outlets have often been blocked.

\section{Recommendations}

Understanding the processes that affect beach production in Antigua suggests several policies and practices. I offer two groups of recommendations here. The first focuses upon the socioecology of the Antigua's coasts and their revitalization. The second group focuses more upon the international political economy of Antigua. I also address sustainability in a way that encompasses both local ecologies and the political economies of development in Antigua.

\section{Sustainable Socioecology}

Reestablishing the basin mangroves that work with reefs to maintain beaches is perhaps the highest priority. However, it is not clear that those former mangrove basins can recover quickly (Pons and Fiselier, 1991). A recent survey of wetland reclamation projects suggests highly variable results and notes that the desiccation of salt marsh soils frequently leads to significant acidification as the soils are exposed to air (Alevizon, 1994). This acidification may be problematic in attempts to rehabilitate coastal wetlands in Antigua and elsewhere. Given that uncertainty, a small pilot project, perhaps at Ffryes Point Salt Pond (see Southern coast map), would be advisable. Due to the magnitude of disturbance, some ponds are pragmatically beyond recovery. The topography of the two very large basin mangrove areas at The Flashes and Jolly Hill (near Five Islands Harbour and Ligum Vitae Bay in Map 2) has been profoundly changed through dredge and fill operations.

Restoration would be expensive if not impossible. However, for many of the other basins, restoration might be relatively inexpensive. The salt ponds at Ffryes Point, Valley Church, Club Antigua, and McKinnon's suffer first and foremost from being cut off from tidal circulation. Channels could be reestablished at a relatively low cost by installing effective culverts under the obstructing roadways. The large pond at Darkwood has been mined for sand and the stream channelized. Infilling the channel near its opening to the sea to enhance ponding would immediately begin to trap sediment and enable mangrove growth. Mangrove transplantation would assist in the reestablishment of the forest. The very large pond at Deep Bay was dredged and all vegetation scraped clear in order to create a "reflecting pond." The result is an unattractive and biotically poor, but still intertidal pond. Because the pond is immediately adjacent to the nine-story Royal Antiguan Resort, it could well serve as a tourist attraction if biotic communities were reestablished in a mangrove park. Raised walkways could give guests access to a reconstructed "natural" area. Due to dredging, much of the pool is now too deep for mangroves. The pool could be made shallower with the spoil from ongoing dredge projects at Deep Bay, the cruise ship harbour at the capital city nearby. Darkwood Pond might also benefit from some infilling to replace the sand that was originally mined from the basin for beach nourishment. Depositing dredge spoil in the pond areas has the added benefit of solving the problems of spoil disposal.

\section{Carte 2}

"Map South" - Southern Caribbean Coast of Antigua:

tourism - and resort - related landscape alterations before development and currently.

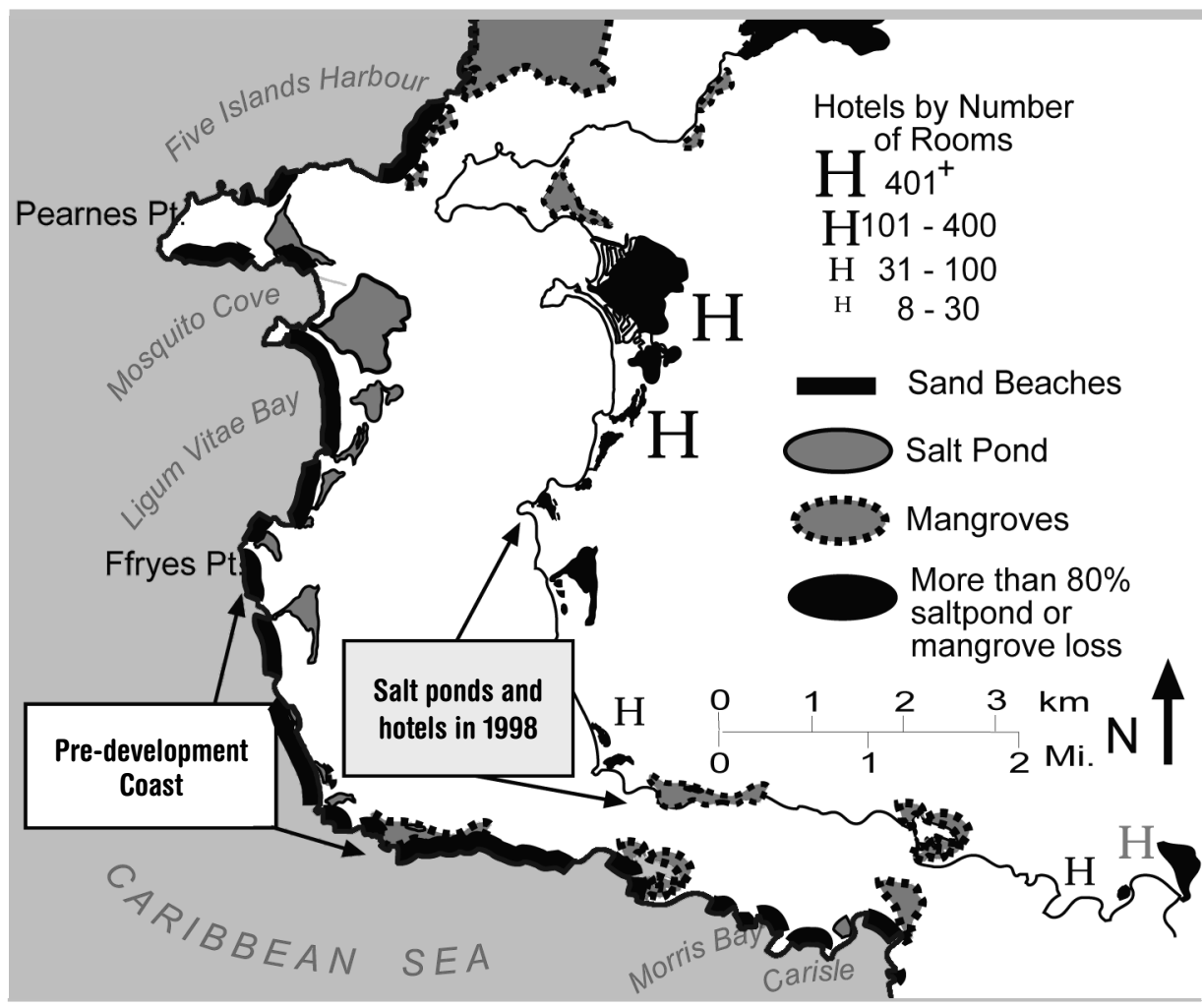

* Beaches are not shown on the contemporary coastline as their extent remains largely unchanged.

Source: Author field survey 1997; ABLSO 1991; Multer et al., 1986; DOS 1977; DOS 1962. 


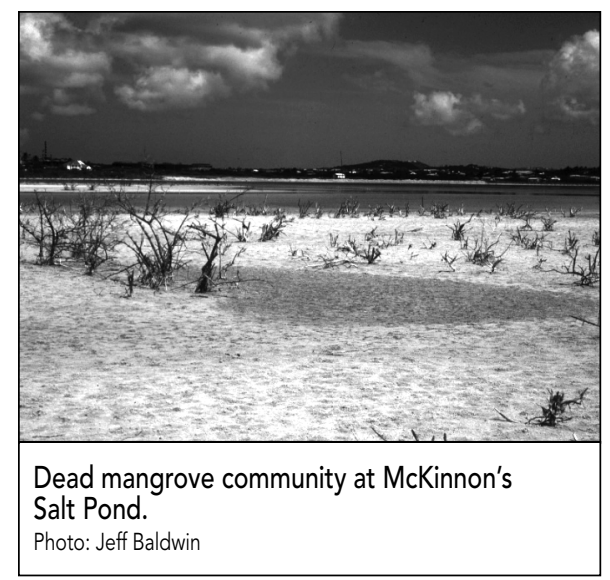

\section{Sustainable Political Economy}

My second set of recommendations involves monetary wealth flows. The geographies of those flows must become more closed, and the spatial withdrawal of local wealth minimized. Government ownership has proven problematic in Antigua (as the International Money Fund has demanded liberalization and due to improper personal involvement in the government's finances) (Coram, 1993). However, local ownership and consequent profit retention remain possible through smaller-scale resort developments (Britton, 1991).

Small resorts are much more within the capabilities of local Antiguan capital—both financial and human. Smaller projects require much more modest financing, an attribute that might discourage some of the shady dealings of the past. They are also more within the capabilities of the Antiguan business class, many of whom have received training in hotel management through the sponsorship of the Curtin Bluff resort and through the Antiguan Hotel Training Center.

Finally, a shift in management practice and policy is essential. The weight of Lester Bird's transgressions swept him from office in 2004. It is too early to tell what if any changes Antigua's new Prime Minister Baldwin Spencer will bring to tourism development and coastal protection policies. However, the laws to protect Antigua's coasts are on the books, the institutions for their enactment require strengthening. A revitalized Development Control Authority and an Integrated Coastal Management Plan as outlined by Bunce (1997) are two potentially productive alternatives.

\section{Conclusion}

Without much imagination one can understand reefs, beaches, and salt ponds as biogenically produced infrastructure (the physical forms life produces to institutionalize flows). They are analogous to human highways, power lines, and neighbourhoods. None of the landscape elements would exist without those living communities; they are physical institutions built by and for nonhuman communities. The flows of sand to the beach and the quiet intertidal environment formed by those sand flows are wealths for mangals. Mangroves stop illthy flows to reefs and transform some of those flows into living wealthy flows to reefs.

Living beings and their communities do produce wealth, often in abundance. Through the power resident in collective bargaining, Antiguans successfully negotiated wages in excess of the survival levels predicted by Marx (1976) (Hector, 1998; Gomes, 1997; Dorsett $1997: 1,3,15)$. They have retained a portion of the "surplus" they produced. The living communities along Antigua's coasts are little different. They also must retain both their productive stocks and a portion of their product in order to persist.

The proposition that humans are able to dominate their wider worlds over the long term is spurious, at best. If the project fails, there is no place else to go. On Barbuda, Antigua's sister island, mining to supply sand to resorts on other islands has destroyed the only fresh water aquifer on the island. Now Barbudans are dependant upon expensive and tenuous water imports and/or desalinization.

The long-term security, stability, and coherence of Antiguans, human and otherwise, lie not in unsustainable dominance over nature, but in collaboration with coastal ecologies, as Bruno Latour suggests in his Politics of Nature (2004). Antiguans can form coalition with coastal communities and still pursue sun, sand, and sea tourism. They need only to respect the claims to the wealth produced by their non-human neighbours, just as the North Atlantic community came to recognize Black Antiguans' claims to their own labour.

Jeff Baldwin, Ph.D., is visiting Assistant Professor. Environmental and Earth Science, Willamette University (Salem, Oregon-USA).

\section{Bibliography}

ABDT (Antigua and Barbuda, Department of Tourism) (1996), Statistical Report 1995. ABDT, St. John's, Antigua.

ABLSO (Antigua and Barbuda, Land Survey Office) (1991), Aerial Survey of Antigua, 1:10,000.

ABMF (Antigua and Barbuda Ministry of Finance) (1996), A Glance at Statistics, Statistics Division, St. John's, Antigua.

AHTA (Antigua Hotels and Tourist Association) (1996), Life in Antigua and Barbuda, West Indies Publishing, St. John's, Antigua, West Indies.

AHTA (Antigua Hotels and Tourist Association) (1997), Tourism Vibes, May.

Alevizon, W.S. (1994), Pisces Guide to Caribbean Reef Ecology, Hong Kong, Pisces Books.

Baldwin, Jeff (2000), «Tourism Development, Westland Degradation, and Beach Erosion in Antigua, West Indies», Tourism Geographies, vol. 2, no. 2, p. 193-218.

Baldwin, Jeff (2005), «The Contested Beach: Recalcitrance and Resort Development in Antigua, West Indies", in Carolyn Cartier and Alan Lew (dirs.), Seduction of Place: Geographical Perspectives on Globalization and Touristed Landscapes, New York, Routledge, p. 338-360.

Baldwin, Jeff (2006), "The Culture of Nature through Mississippian Geographies», Ethics and the Environment, vol. 11, no. 2, p. 11-43.

Bourdieu, Pierre (1986), The Forms of Capital. Handbook of Theory and Research for the Sociology of Education, New York, Greenwood Press.

Britton, Stephen (1991), «Tourism, Capital and Place: Towards a Critical Geography of Tourism", Environment and Planning D: Society and Space, vol. 9, p. 451-478.

Bunce, L.L.M. (1997), Integrated Coastal Zone Management of Common Pool Resources: A Case Study of Coral Reef Management in Antigua, West Indies, unpublished dissertation, Duke University.

Burac, Maurice (1996), «Tourism and Environment in Guadeloupe and Martinique», in L. Briguglio et al. (dirs.), Sustainable Tourism in Islands and Small States, New York, Pinter, p. 63-74.

Butler, R. (1993), "Tourism: An Evolutionary Perspective», in J. Nelson, R. Butler and G. Wall (dirs.), Tourism and Sustainable Development: Monitoring, Planning, Managing, Waterloo, Heritage Resources Center, University of Waterloo, p. 27-43.

CCA (Caribbean Conservation Association) (1991), Antigua and Barbuda: Country Environmental 
Profile, United States Agency for International Development/ USAID, Bridgetown, Barbados.

Coram, R. (1993), Caribbean Time Bomb: The United State's Complicity in the Corruption of Antigua, New York, William Morrow.

Corbin, Alain (1994), The Lure of the Sea: The Discovery of the Seaside in the Western World 1750-1840 (trans. J. Phelps), Cambridge, Polity Press.

COSALC (Coast and Beach Stability in the Lesser Antilles) (1996), Beach Erosion in Antigua and Barbuda Coast and Beach Stability in the Lesser Antilles, San Juan Puerto Rico, Sea Grant Printers.

Costanza, Robert, Lisa Wainger, and Nancy Bockstael (1995), «Integrated Ecological Economic Systems Modeling: Theoretical Issues and Practical Problems", in Walter Milon and Jason Shogren (dirs.), Integrating Economic and Ecological Indicators: Practical Methods for Environmental Policy Management, Westport, Connecticut, Praeger.

Courier (The) (1997), Antigua and Barbuda Profile, vol. 50, no. 5, p. 44.

Dorsett, E. Bishop (1997), «Bishop Dorsett Speaks Truth to Power», Antigua Outlet, July 1.

DOS (Directorate of Overseas Surveys) (1977), Tourist Map of Antigua, West Indies, 1:50,000, Government of Great Britain, London.

DOS (Directorate of Overseas Surveys) (1962), Antigua Island, 1:25,000, Government of Great Britain, London.

Edington, J.M., and M.A. Edington (1986), Ecology, Recreation and Tourism, Cambridge, Cambridge University Press.

EC (European Commission) (1996), EAU-ACP Cooperation in 1995: What Form of Structural Adjustment?, European Union, Brussels.

Foucault, Michel (1970), The Order of Things: An Archaeology of the Human Sciences, New York, Random House.

Gomes, Lionel (1997), Unpublished author interview, June 27, St. John's, Antigua, West Indies.

Goodpaster, Kenneth (1978), «On Being Morally Considerable», Journal of Philosophy, vol. 75, p. 308-325.

Gortier, H. (1997), «Antigua and Barbuda: Paradise Troubled», Courier, vol. 162, p. 32-36.

Gourlay, M.R. (1994), «Wave Transformation on a Coral Reef», Coastal Engineering, vol. 23, p. 17-42.

Hall, Michael, and Stephen Page (1996), Tourism in the Pacific: Issues and Cases, Albany, New York, International Thomson Business Press.
Hall, Michael, and Stephen Page (1999, $2^{\text {nd }}$ ed.), The Geography of Tourism and Recreation; Environment, Place and Space, New York, Routledge.

Harris, J.E., and J.G. Nelson (1993), «Monitoring Tourism From a Whole Economy Perspective: A Case From Indonesia", in Nelson, Butler and Wall (dirs.), Tourism and Sustainable Development: Monitoring, Planning, Managing, Heritage Resource Centre, University of Waterloo, p. 179-200.

Hector, Timothy (1998), «Immigrant Labour First, Local Labour After or Last», [http://www. candw.ag/ jardinea/f97sept04.htm], (accessed September 4).

Ho, Mae-Wan (1993), The Rainbow and the Worm: The Physics of Organisms, New Jersey, World Scientific.

Hughes, George (2002), «Environmental Indicators", Annals of Tourism Research, vol. 29, no. 2, p. 457-477.

Inman, D. (1994), «Types of Coastal Zones: Similarities and Differences in Environmental Science", in The Coastal Zone: Issues for Further Research, The National Research Council. Washington, District of Columbia, National Academy Press.

Latour, B (2004), Politics of Nature: How to Bring the Sciences into Democracy, Cambridge, Massachusetts, Harvard University Press.

Laycock, Steven (1999), «The Animal As Animal: A Plea for Open Conceptuality", in Peter Steeves (dir.), Animal Others: On Ethics, Ontology, and Animal Life, Albany, New York, SUNY Press, p. 271-284.

Lefebvre, Henri (1991), The Production of Space, Oxford, Blackwell.

Lencek, L., and G. Bosker (1998), The Beach: The History of Paradise on Earth, New York, Viking.

Maragos, J.E. (1993), «Impact of Coastal Construction on Coral Reefs in the U.S.Affiliated Pacific Islands", Coastal Management, vol. 21, p. 235-269.

Marx, Karl (1976), Capital: A Critique of Political Economy, vol. 1 (trans. B. Fowkes), New York, Vintage.

McElroy, J.L., and K. De Albuquerque (1988), "Migration Transition in Small Northern and Eastern Caribbean States", International Migration Review, vol. 22, no. 3, p. 30-58.

McElroy, J.L., and K. De Albuquerque (1991), "Tourism Styles and Policy Responses in the Open Economy-Closed Economy Environment Context», in N.P. Grivan and D. Simmons (dirs.), Caribbean Ecology and Economics, Barbados, Caribbean Conservation Association.
Minerbi, L. (1992), Impacts of Tourism Development in Pacific Islands, San Francisco, Greenpeace Pacific Campaign.

Multer, H.G., M.P Weiss, and D.V. Nicholson (1986), Antigua: Reefs, Rocks and Highroads of History, Leeward Islands Science Associates, St. John's, Antigua, West Indies.

Mumby, P.J., et al. (2003), «Mangroves Enhance the Biomass of Coral Reef Fish Communities in the Caribbean", Nature, vol. 427, no. 6974, p. 533-536.

Patullo, P. (1996), Last Resorts: The Cost of Tourism in the Caribbean, London, Cassell.

Plumwood, Val (2002), Environmental Culture: the Ecological Crisis of Reason, New York, Routledge.

Pons, L.J., and J.L. Fiselier (1991), «Sustainable Development of Mangroves», Landscape and Urban Planning, vol. 20, p. 103-109.

Ramrattan, P. (1997), Unpublished author interview. St. John's, Antigua, West Indies.

Serres, Michel (1982), Hermes: Literature, Science, Philosophy, Baltimore, Johns Hopkins University Press.

Shields, Robert (1990), Places on the Margin, London, Routledge.

Symonds, G., K.O. Black, and I.R. Young (1995), "Wave Driven Flow Over Shallow Reefs", Journal of Geophysical Research, vol. 100, p. 2639-2648.

Tam, M.Y.F., and Y.S. Wong (1995), «Mangrove Soils as Sinks for Wastewater-borne Pollutants», Hydrobiologia, vol. 295, p. 231-241.

UPR (University of Puerto Rico) (1994), Caribbean Newsletter, April-June.

Wilson, David (1996), «Glimpses of Caribbean Tourism and the Quest for Sustainability in Barbados and St. Lucia», in Briguglio et al. (dirs.), Sustainable Tourism in Islands and Small States, New York, Pinter, p. 80-92.

Wong, P.P. (1993), «Tourism and Environment: The Case for Coastal Areas», in Dordecht, Netherlands, Kluwer, p. 83-97.

Young, I.R. (1989), «Wave Transformations Over Coral Reefs", Journal of Geophysical Research, vol. 94, p. 9779-9789.

Zachariah, E. (1997a), "What Is Making the Beaches in Antigua Erode?», Part 1, Antigua Sun, June 13, p. B-6.

Zachariah, E. (1997b), «What Is Making the Beaches in Antigua erode?», Part 2, Antigua Sun, June 20, p. A-11. 